\title{
Towards an Islamic Social (Waqf) Bank
}

\author{
Mohammad Tahir Sabit Haji Mohammad
}

\begin{abstract}
This paper looks at the permissibility of establishment of a waqf (a non-profit social bank) in Islamic law. Considering the needs of the poor majority in all Muslim nations, unattended to by current banking system, it explores and extends the views of Muslim jurists regarding the validity of cash waqf to the permissibility of waqf bank. Cash waqf donations and proceeds can be used to form the capital of the bank. The principles of waqf and its perpetuity and the protection of the cash waqf can also apply to the capital of the bank. The structure of this bank and its functions has to be in conformity with waqf principles too.
\end{abstract}

Index Terms-Cash waqf, waqf bank, Social bank.

\section{INTRODUCTION}

Waqf in Islam is both charity and enterprise thus could be a self-sufficient NGO or organisation. Waqf refers to Islamic public charity or trust for socio-economic causes, whereby the object or property is perpetually non-transferrable; an object, under this type of charity, is donated so that the beneficiaries can enjoy it, or the trustee of the charity is required to give the income of it to them. A donor may give any type of property but the preferable one is immoveable. Properties the income of which is distributable on the beneficiaries is the dynamic form of waqf which make these charities enterprises that should be treated as any investable property in current business terms and the best use and maximum income of which needs to stressed. The subject of this paper is cash properties in both consumptive and productive senses i.e. the cash used for loans and the cash which is intended to generate income and such income is dedicated to be distributed on the beneficiaries.

This conceptual paper is the revised version of a research report (2006-2008) exploring, in Islamic law, the permissibility of a would-be waqf bank in Muslim Countries. The proposal is for the establishment of an interest free, not-for-profit, and social bank dedicated mainly to the social welfare, provision of micro financing, and economic development of the poor and under privileged. It is proposed as an alternative to the existing privately owned micro financiers (Yeman, Bahrain, Bangladesh and other models), and the non-profit VakifBank of Turkey, the latter being substantially owned by charitable foundations, 'set up during the Ottoman Empire period', to manage their 'cash revenues and expenditures' [24].

Manuscript received July 25, 2011; revised September 13, 2011.

This work was supported in part by the Ministry of Higher Education under Grant Code 78067. The writer is also grateful to the Research Centre, Universiti Teknologi Malaysia for their constant support and encouragement.

M. T. Sabit is with the Universiti Teknologi Malaysia, Johor, Malaysia (e-mail: mtahir@utm.my).
The aim of this article is to offer solution for the two problems of waqf institutions: one, it is specific to those institutions whose waqf properties are either underdeveloped or abandoned due to the lack of development funds. They themselves cannot do it because the majority of waqf properties are fixed assets, which are illiquid. These institutions cannot go to conventional banks (Islamic or otherwise), because waqf properties are inalienable and thus cannot be used as a security for targeted loans. Though several modes of financing for the development of waqf properties are developed recently, however, their utility is limited; there are few financiers willing to participate in these new waqf financial schemes; the trustees are reluctant because they are less profitable, and fear loss of waqf properties; and there is still some legal uncertainty surrounding these methods. Two other ways are proposed early: namely, saham waqf (Waqf Real Estate Share Units) and cash waqf (cash being donated as waqf). Both, so far, have limited results because they are new, there is lack of aggressive campaign and others. Thus over all waqf institutions have inadequate liquid asset, which cannot effectively help them finance the development of waqf properties. The second problem is the inability of the waqf institutions to participate in the welfare projects of the community as much as one expects them to do. This again is due to the lack of adequate waqf funds to undertake such projects. Therefore, this article proposes a waqf bank whereby the problem of illiquidity and inadequacy of funds for the financing the development of waqf properties specifically and the inability to participate in many socioeconomic projects helping many poor and needy generally can be tackled.

Two banks, which have connection with this topic, do exist but they are not what this article proposes. The Turkish VakifBank is interest-based and state-owned institution, and therefore its model cannot be entirely followed, though the distribution of dividends on its shareholders, which are Muslim charitable foundations, can be an example for a new waqf bank. There also exists an Islamic Social Bank in Bangladesh, which is private corporate bank in its conventional sense. It only collects and manages cash waqf for the beneficiaries. Thus, such a bank is not really a waqf bank. Presuming the Turkish VakifBank is a true waqf bank there is still need for this study, as the permissibility of such a bank is not explored yet. To fill this gape this paper looks at its permissibility from perspective of cash waqf, the need for it, and its operation.

The idea of having a waqf social bank is attractive because it can make liquid assets available for financing the development of waqf properties, as well as to have adequate cash and income ready for disposal on various socioeconomic projects. A conventional bank earns by 
collecting deposits, granting loans, providing liquidity, and transferring funds and payment system [17], selling insurance and investment products, and stock brooking [8]. They also charge transaction fees on financial or overdraft services, and earn interest on lending. Islamic banks do earn the same but avoid usury, uncertainty (gharar), gambling, and investment in prohibited (haram) businesses. A waqf bank would do the same, while complying with the rules of waqf. It then can be a very good source of income to waqf institutions. The income from services, fees, and investment including the time and demand deposits will enable the waqf institutions to develop waqf properties and participate in other social welfare and micro financing projects. However, several questions arise as to the viability of such a bank.

Should the capital of waqf bank be waqf? Can cash be the subject of waqf in Islamic law? Who should own and manage waqf bank and how it should operate? For this, the permissibility of cash waqf and a waqf bank as well as its business and structure are briefly explored.

\section{The PermissibiLity Of A WARF BANK}

A waqf bank can be allowed in Islam if an existing rule of permissibility is extended to it; it has its own intrinsic utility that is in the interest of waqf, its beneficiaries, Muslims and the society in general. Additionally it can be permitted, if its structure and operations are compliant with Shariah.

\section{A. The Permissibility of Cash Waqf}

Things that can be donated, as charity, is not settled in Islamic law. The majority of Muslim jurists recognises the validity of immoveable property as the subject matter of Islamic charity due to its nature, which is perpetual. Moveable goods are permitted as an exception to the general rule, because such permission is found in the main texts of Shariah (the Sunnah). Therefore, classical jurists are divided on the validity of cash waqf, probably due to the perpetual nature of waqf assets, which is not apparent to some in cash. Few in the past and more today find perpetuity in cash, if it is used for loans or investment [21]. The contemporary jurists also justify the validity of the cash waqf, because it is in the interest of the waqf, its beneficiaries and the society.

The classical jurists differed on gold and silver coins as the object of waqf. Imam Abu Hanifah and Abu Yusuf [22], a view in Maliki School, the majority of Shafi's, and a view of Imam Ibn Hanbal consider cash not a valid object of waqf [25]. On the other hand, Imam al-Zuhri [12] and Imam Zufar [7], [10], among founders of juristic thought, permitted cash waqf. The majority of later Maliki jurists, late pre-modern Hanafi jurists allowed cash waqf. Similarly, in Hanbali School Ibn Taymiyah [23] considered the permissibility of cash waqf a preferred view in the school. The Shafi'i School is less inclined to allow cash waqf [21], [14], despite a report from Imam Shafi'i to the contrary [1]. Al-Mawardi [1] restricted the view of Imam to the donation of benefits or income, when the coins are rented. He reported two views: one for the permissibility of it, and another about its invalidity. The view of Imam Shafi'i, as understood from al-Mawardi [1] description, is not restrictive. It is presumed, al-Mawardi [1] may have attempted such restriction based on his own criterion of waqf objects: anything of uninterrupted existence and capable of utilisation. Coins in his view may not exist uninterruptedly, unless used for rental. Such a criterion is not necessary while a different principle in the school i.e. capable of recurrent benefit or use $[14 ; 26]$ can make the objective of waqf achievable.

The Hanafi jurist Imam Zufar considered cash capable of meeting the criterion of perpetuity, when the donated cash is used in mudarabah trade and the income is distributed among the beneficiaries [7] [10], [27]. Ibn Abidin and others [10], however, have brought the permissibility of cash waqf under the ruling of Imam Muhammad who allowed moveable properties as waqf, if that is the practice of the community. Ibn Abidin [10] admitted the practice of cash waqf in Roman and non-Roman Territories during the Ottoman Empire [10] [13]. This view of Ibn Abidin [10], however, may not be able to justify cash waqf when such a practice is about to start. Tamartashi allowed cash waqf unqualified, and Hskafi [5] thought that this is due to the decision of courts [10]. Ibn Abidin, [10] in an unrelated passage, however, viewed coins as non-specific replaceable property. If loaned or lost, recovery and restitution of the coins are made in similar units. Through this substitution of one unit with another, money exists forever [3], [10]. One, therefore, can understand Hanafi view to propose the perpetuity of coins, and hence the perpetuity of such a waqf. This is true about the Maliki and Hanbali schools too. The Malikies report from Imam Malik the permissibility of cash waqf for purposes of loans [20]. Ibn Taymiyah [23], from Hanbali School, on the authority of Abu al-Barakat, allowed cash waqf for lending or investment (tanmiyah).

A Western scholar viewed the practice of cash waqf in the Ottoman Empire usurious piety [6]. However, this may seem so, if one comes up with a scheme requiring a fixed percentage through bai' al wafa; otherwise the view of Imam Zufar in the sense of mudarabah is not even close to usury.

Contemporary jurists agree with the rule on permissibility of cash waqf [3], [4], [11], for the purpose of loans [11] and investment in bank and bonds [9], [16], [21]. Ammar extended the rule from coins to currency and other liquid assets, such as company shares, certificates and bonds.

Contemporary jurists also accept cash waqf because of its inherent utility, some forms of which are listed below. Dunya [21] listed the significances of cash waqf as: (a) compare to immovable property many members of the public have cash. (b) Cash waqf is the best way for a joint waqf (waqf mushtrak/waqf juma'i), thus, it can attract finance for the development of diverse and big projects. (c) Cash waqf can be invested in diverse economic activities, and therefore greater revenue can be expected. (d) It can be for any objective, and any social purposes. (e) The chances for the growth of this waqf are higher. Maiman [16] added that it is easily liquefiable compare to realty. Ammar [2] further listed the benefits of cash waqf. They are: (i) currency as the replacement of coins is the medium for exchange of goods. (ii) Currency is replaceable with similar (i.e. it is a mal mithli). (iii) Cash waqf enables every one to donate as waqf, whereby the poor and needy can benefit from the abundance of resources. (iv) Cash waqf is capable of creating more economic stimulus, and it can be a welfare fund used to 
sponsor many educational, social and health projects.

To sum, the coins of the old, the paper currency of today, or any other form of liquid asset, under modem banking practice, can be the object of waqf [2], [16]. For the purpose of loans and investment, currency will be more useful to a bank, while other forms may end up in non-liquefiable asset, unless prudent deeds of waqf are in place, empowering the bank to use certificates of shares, sukuk and others as currency.

\section{B. From Cash Waqf to Waqf Bank}

The permissibility of cash waqf can be extended to waqf bank for several reasons. Almost all waqf issues are rational (ijtihadi). An analogy on another ruling of Shariah can provide legitimacy of waqf bank. The establishment of a waqf bank could also be allowed, if it could be for the benefit of waqf, its beneficiaries, and is in the interest of public (maslahah amah).

\section{1) Analogical Reasoning}

Waqf Bank is not against Shariah principles. There is no primary text in Islamic law prohibiting the establishment of waqf bank, and almost all waqf issues are rational. Since ultimately the waqf bank will have waqf capital, predominantly in cash, the permissibility of cash waqf then can be extended to waqf bank. As established in the preceding section, cash waqf is permissible in Islamic law and therefore such shall be true about a waqf bank.

The function of cash waqf can be the function of a waqf bank. The former is allowed for loans to the needy, and investment through mudarabah, mu'malah, and ijarah. If a wider application is given to the idea, a waqf bank can use such cash waqf for the same purposes. Thus, the permissibility of a waqf bank and its operation will not be only supported by the permissibility of cash waqf, but its benefit to all parties concerned. It can operate as follow.

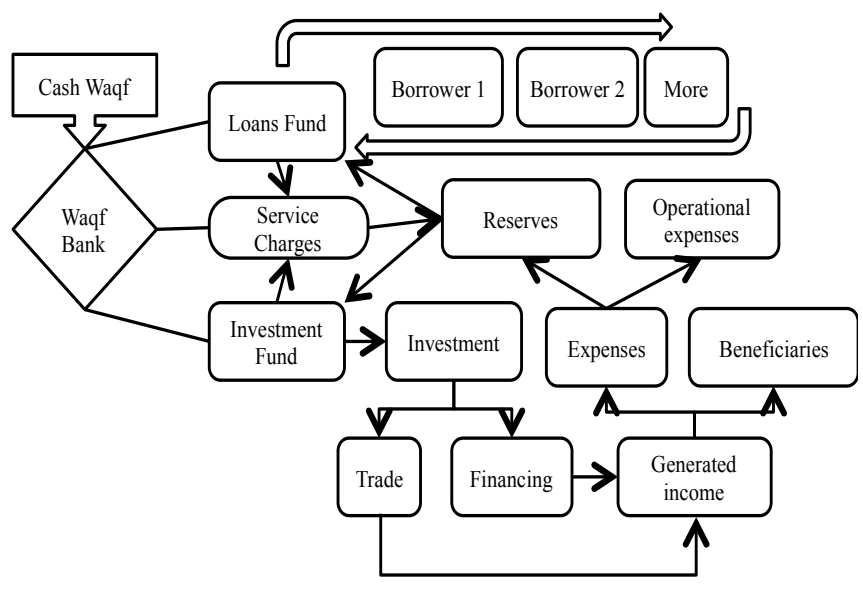

Fig. 1. Waqf Bank's Proposed Structure and Operation

First, the bank can be entrusted with cash waqf or collect cash waqf from the public for special purposes disclosed and easily available to the donating public. As illustrated in fig.1, once such deposits are made, the bank can disburse the cash, which is dedicated for loans, to the indebted, for marriage, and for any other welfare project. As borrowers settle a loan, the repaid amount can be once again loaned to another. This will be repeated whenever an amount is available in the given fund. The cash can be maintained perpetually, provided compensations for losses and market fluctuations are planned and paid. For this, a special account called the reserves account will be needed. As the Loan's Fund will be disbursed interest free, minimum service charges will be imposed on borrowers, a proportion of which can be for making good on losses and damage suffered by the fund. Second, the waqf bank can be entrusted with investment deposits or its own waqf capital. The same as cash waqf, the bank has to operate the entrusted capital in an income generating business. This capital is not to be used for purposes other than investment; its protection and growth will be the main function of the bank. Such funds are established to use its income for the benefit of the society or the purpose for which the donors have dedicated them. Therefore, the capital has to be invested in any permissible transaction capable of generating income. This is possible if the mudarabah of Hanafis [7], [10], [27] can be broadened to include fund management, the rental of coins by Shafi' is' ijarah i.e. based transactions [1], [26], and Ibn Taymiyah's concept of tanmiyah (growth) to any form of Shariah Compliant investment transaction, as practiced by Islamic banks. The waqf bank can use all these modes (see fig. 1). This is particularly true in the case of cash, which is not donated to be disbursed for loans. In other words, the bank will use cash the income of which is dedicated for welfare, in the majority of its investment transactions.

As a rule, productive waqf must be kept invested and income generating, which can be best achieved by going to the business of banking. The contemporary Islamic banking practice provides evidence of successful cash investment methods that are not only good for expecting good returns on the investment but also protection of the capital which will be discussed in due course.

Additionally, as illustrated in fig. 1, the bank will use cash waqf for its capital according to fiqhi principles in its operations (both loans and investment). Therefore, the core characteristic of waqf i.e. perpetuity of the object or the capability of recurrent use and benefit, would apply to both the cash waqf and waqf bank alike.

2) The Utility of a Waqf Bank

A waqf bank can be permitted based on its utility i.e. the need of waqf, its beneficiaries, and the general interest of the society (maslahah amah). This can be illustrated by its operation and its main purposes for which it is established as discussed in the early section.

The utility of waqf bank is clear. Muslims and the society need a compassionate bank, that can offer its resources to the needy, require no collateral, and cause no distress to the borrowers. Other banks do not fill this gape. Since the society will own the bank and the bank will not be concerned with profits, especially when loans is service based and not for making profits, the chance of benefiting the society are higher. Poor will have access to wealth with very low cost. The bank can be a true pro poor redistributive national wealth management tool for micro and macro economic planning of a nation.

The bank will benefit waqf, and its beneficiaries, as it can provide adequate capital to waqf institutions (fig. 2). It can attract a large sum of cash, both waqf and non-waqf. It is possible that the mission and the ethical system of the bank will attract many individuals and entities either to donate or 
to save and earn profits. The bank as an intermediary, then, can mobilize the demand and time deposits to borrowers when applied for, or invest them to earn profits through its investment activities, including trade and financing. The bank can earn by providing various banking services, when it provides retail and commercial services to its individual, corporate, and other clients on daily basis. Just like any other bank, the waqf bank after its establishment can make hundreds of millions annually. These profits plus deposits can finance the development of existing or new waqf properties, which are idle or underdeveloped. The institutions of waqf would be independent then, for they would need not to seek finance from other sources, such as conventional and Islamic banks. The bank, therefore, can enable the institutions of waqf to save waqf property from being lost due to dilapidation and ruin. Once the waqf properties are developed they would be able to generate income, and more so in the case of underdeveloped properties. It is, thus, very clear that the newly established bank can provide better protection for the waqf properties and can also enable waqf to contribute to many high value socio-economic projects. These projects would be carried out for investment purposes or otherwise. In either case, the beneficiaries of waqf can have access to more assistance or have more income. The bank can also provide effective assistance to those who are poor and have no access to credit. It is clear in achieving these goals; the bank can provide indirectly various employment opportunities to many individual choosing to work with the bank. This and the benefit received by beneficiaries or those who borrowed and financed their projects through waqf bank will certainly enhance the GDP of a nation.

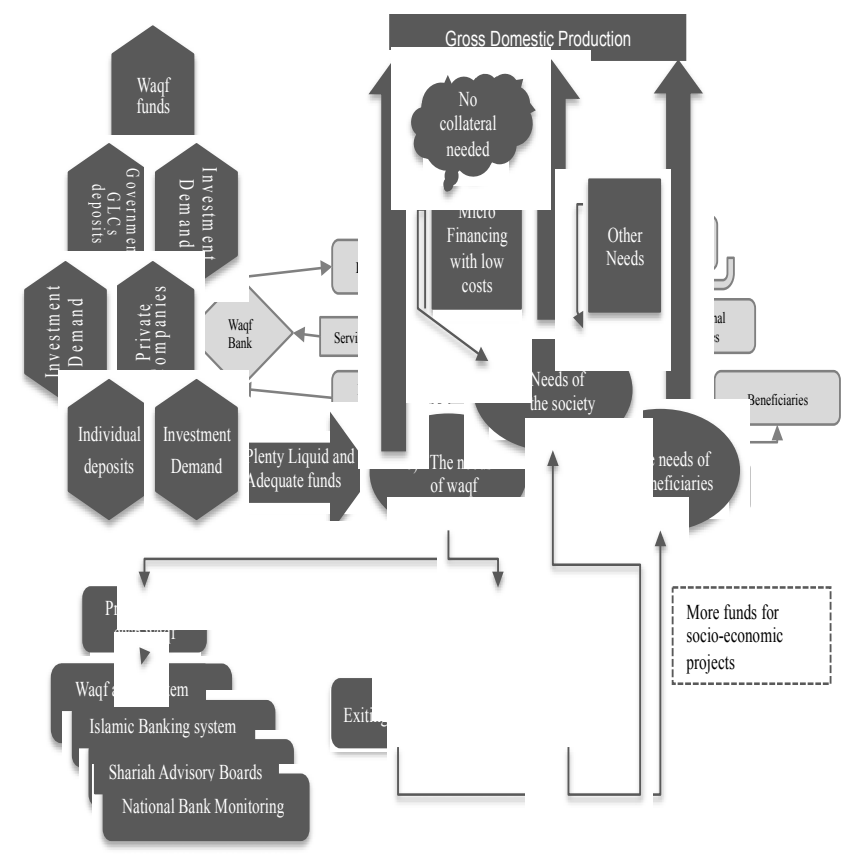

Fig. 2. Waqf Bank and its Utility to Waqf and Society

As mentioned above, the waqf bank will provide liquidity for waqf institutions. The liquidity will assist these institutions to revive their non-productive and productive waqf properties. Productive waqf refer to those properties, which are dedicated by their owners to be kept income generating and such an income is to be used for a specific charitable cause. It is the duty of the trustee to keep these properties productive and income generating. However, in many events the trustee fails to keep these properties productive, for they are ruined or in dilapidated state. Since they are overwhelmingly fixed assets, and thus can be used only for the purpose of cultivation or rental, the trustee will be unable to revive them. Financing their development through conventional banking system may not be easy for the trustee of these charities, for the collateralisation of these properties is prohibited under Islamic law. For this reason some institutions will be weak in the development of their properties, thereby failing constantly in delivering the intended benefits to the beneficiaries. This is not only failure of these institutions to fulfill their duty towards the beneficiaries of a specific trust, but also a blow to the general benefit and purpose of the institution of waqf. A waqf bank can certainly save these institutions from both of these failures.

A waqf bank can protect cash waqf. All cash waqf funds need to be protected from losses and misappropriation. When used as the capital of a waqf bank, cash waqf may have higher chance of perpetuity, as required by many jurists. This is so because the business of banks is the making of money and aversion of unreasonable risky ventures. Additionally, banks are corporations and need to manage its affairs according to strict rules of relevant law. Banks are also subject to further restrictions from the Central Bank for maintenance of its capital, including the various transactions in which its capital is used. A waqf bank will additionally be regulated according to the principles of waqf. It can be audited and supervised by the Shariah advisory board. Some of these facilities are not available to cash waqf funds.

The institutions of waqf will not have to worry about loosing the waqf assets to non-waqf entities. They can obtain loans from the waqf bank on investment basis. Upon repayment of the sum, the bank can benefit from its investment and the borrower institutions from the increased generation of income from the recently developed waqf property. In case the borrowing waqf institution is unable to meet its obligations, the bank either can extend repayment time and restructure the terms of the contract or take possession of the waqf property for the purpose of better management. A third independent party can manage the property. Once the bank receives its capital plus the agreed sum of the profits, it can return the waqf assets to the original trustee.

In country such as Malaysia where the institutions of waqf are caught between States and the Federal Government under the constitutional principle of separation of powers, the creation of a waqf bank will be a blessing. All waqf institutions can easily approach the bank, irrespective of whether or not they own it. Jurisdictional restrictions will not hinder such dealing with the bank.

Above all, and in disregard to no such weaknesses, the proposal for attracting more funds is needed. This will make the institutions of waqf have wider welfare utility and many people will benefit from it.

Furthermore, the establishment of waqf bank as a social bank is the need of the twenty first century. Looking at the 
unsustainable development patterns, the growth of neoliberal economic order, and the individualistic tendency of present generations, current banking systems including Islamic prove themselves to be unable to assist the major sections of societies. The gap between the rich is going wider, inequality of income, the concentration of wealth in a small $20 \%$ of the global population, the high level of poverty in Muslim and other developing countries and the increase in the number of old people in advanced societies makes the need for a social bank urgent more than ever. The proposed waqf bank can help the state in provision of decent living standards to its citizens including shelter, education, healthcare, employment and the like.

In brief, a waqf bank can be permitted based on the permissibility of cash waqf and its uses, the need and interest of society, as well as the need of waqf and its beneficiaries. The above reasons alone may persuade the permissibility of waqf bank, the structure of which needs to be briefly examined.

\section{3) Compliance of the Structure and Operation of a Waqf}

\section{Bank with Existing Laws and Shariah}

A waqf bank should be licensed upon incorporation in accordance to the requirement set by the Central Bank and the existing laws. The main laws applicable to waqf bank will be the Islamic Banking Act, [19], the Banking and Financial Institutions Act, [17], the Companies Act, [18], and other regulations.

Following the Companies Act, the waqf bank can be registered as private limited company or public limited. Upon registration it must have owners, capital, objectives and internal rules of governance. The intended waqf bank can easily meet these requirements. It will be a legal person, which can own moveable and immoveable assets, including land. It can sue others and may be sued by others in its own name.

The waqf institutions, or these institutions and other parties can solely or jointly, as the case may be, control the ownership of the bank. When only the institutions of waqf are the owners of the bank, they can start business by registering the bank as a corporation regardless of whether the bank is owned by two or many waqf institutions. The bank can also be formed as a corporate body, if the founders of the bank could invite public and private sector to take part in the capitalization of the bank by buying its shares. The joint venture with non-waqf entities should not be legally a problem, as the normal rules of perpetuity applicable to fixed waqf assets will not apply to cash waqf. The institutions of waqf when offering the shares of the bank to these corporate and other entities can obtain an undertaking from these non-waqf entities to sell back their shares willingly to the bank when the bank is financially fit and shows interest in the purchase of their shares. The bank can also be formed as a cooperative if various institutions of waqf own it.

Subject to the minimum capital required by Central Bank, according to the prevailing banking laws and regulations, the bank could initially raise its capital through benevolent loans and investments from governmental, semi governmental, and corporate bodies, and waqf funds, either cash waqf or the proceeds of other waqf properties. As mentioned by Dunya [21] and Ammar [2] cash waqf may be individual or group donations dedicated for one or more causes through a specific project or otherwise. If there is will on part of all waqf institutions, self-capitalisation of the waqf bank by these institutions from their liquid assets could be possible. Waqf institutions can also raise hundreds of millions through cash waqf [15]. If such cash waqf is invested prudently, the income together with its principle can be used as capital for Waqf Bank later. For instance, it is now established that waqf institutions are asking the public to donate RM10. If this amount is promoted aggressively, and have a pool of 2 million donors for five years who can contribute the same amount on monthly basis, there will be enough cash waqf funds to establish a waqf bank. In case the waqf bank is established early as a joint venture between waqf intuitions and corporate bodies, the institutions of waqf will be able to purchase all subscribers' shares in the waqf bank, and thus will make waqf bank a $100 \%$ waqf property.

Among its objectives, waqf bank can accept all types of deposits, from any willing individual or body. The bank would have to invest the funds and share profits with investors. It could raise cash waqf and collect zakat. It can invest and use all the deposits and reserved funds, and distribute the generated net profits on investors and the bank. The profits of the bank, along with zakat, can be distributed on welfare projects, and micro financing according to Islamic law. The funds marked for loans can also assist the bank rescue its bad investments by offering benevolent loans or aid to its clients according to the principles of waqf loans and zakat. The bank can finance various development and commercial projects including waqf properties. It can impose minimum fees and charges to compensate for expenses and currency depreciations (see fig. 2.). The investment of cash for loans will be on short term. Productive waqfs can be invested for short or long term, provided a good management practice dictates it.

As an Islamic bank, the waqf bank has to follow the rules of Islamic law. It has to comply with Islamic Banking Act 1983, and do business accordingly. The bank as a manager of waqf funds will also have to invest according to the special characteristic of waqf properties and in line with duties of trustees that is to safeguard waqf capital and increase its income. It would have the duty to retain the principal, distribute its income, minimize investment risk, take contingency measures for depreciation and other risks, and apply for tax exemption whenever the law provide for. It must give priority to projects that is in line with Shariah objectives (maqasid Sharia), beneficial to local population, and in the interest of beneficiaries. Investment methods, which involve relatively higher risk, can be avoided [21]. The bank could reserve a portion of income for contingencies and invest them to generate income in order to increase its reserved funds. The bank can also liquidate some of the waqf properties as and when it is considered profitable and does not clash with the interests of the waqf and its beneficiaries. This will not be against Islamic law, for the principle of perpetuity will apply to the capital realised through cash not the secondary objects or the commodity purchased through the capital.

Waqf bank would be required to maintain its capital. Several measures against misappropriation and 
mismanagement of the funds will be in place. The restrictions imposed by the founders of the waqf, the principles of Islamic law, adherence to the best practice, and banking regulation, will enable the waqf bank to maintain its capital. It will be required to have and maintain reserve fund including statutory reserves, and to have in possession minimum liquid assets. The bank will be subjected to annual audit.

The bank will be subject to the supervision of the Sharia Advisory Board, shareholders, and the Central Bank. All these bodies will scrutinise the performance of the bank and therefore the dismissal of negligent and incompetent individuals will be easy when proved the bank has suffered losses due to their malicious intentions or negligence. It will be easy to hire and fire fund managers when they do not deliver what are expected of them.

\section{SUMMARY}

Waqf being a charity for public welfare, which is capable of generating income through and for its projects deserves due attention so that it can assist itself and the large segment of the society. One step towards that direction is the allocation and concentration of adequate liquid funds to and in this kind of third sector. The tool for this is perceived to be the establishment of a waqf bank.

The waqf bank can be the bank of the poor and underprivileged. It can be permissible in Islam based on validity of cash waqf and the need of waqf, its beneficiaries as well as the society. It can maintain the waqf capital due to its business model and internal as well as external supervision. It is therefore viable legally and practically.

The institutions of waqf have the unrealized potential to establish a Waqf Bank. If there is favourable political will, the institution of waqf, through waqf bank, can greatly contribute to society. The bank will enable waqf institutions not only solve their current problems of inadequacy and illiquidity, but can make them more self-reliant. In view of current economic uncertainties throughout the globe and the unequal distribution of wealth, one can strongly argue that there is need for the revival and further development of such an old noble ideas. We need to welcome them irrespective of where and who offer them.

\section{ACKNOWLEDGEMENT}

The writer is grateful to the Malaysian Ministry of Higher Education, Universiti Teknologi Malaysia and particularly the Research Centre of this University for supporting this work through small research grant, which made this paper possible. Thanks also go to colleagues at the Centre for Real Estate Studies, Department of Land Administration and Development at the Faculty of Geoinformation and Real Estate, Fatin Afiqah (Ph.D. candidate) and all those who directly or indirectly made this work possible.

\section{REFERENCES}

[1] A. H. Mawardi, (d. 450 A. H). al Hawi al-Kabir. Vol. 3. Beirut: Dar al-Kutub alllmiyah, 1999.

[2] A. M. Ammar. Waqf al-Nuqud wa al-Awraq al-Maliyyah. A'mal Muntada Qadaya al-Waqf al-Fiqhiyyah al-Thaniyyah, Tahddiyyat Asriyyah wa Ijtihadat Shar'yyah. Kuwait: IDB, Kuwait Awqaf Public Foundation, 2006.

[3] Abu Zahrah. Muhadarat fi al-Waqf. N.pp: Dar al Fikr al-Arabi. 1971.

[4] Fatwa 140(6/15) 11/3/2004, Qararat wa Tawsiyat Nadwah al-Barakah li al-Iqtisad al-Islarni, fatwa 18/1, 2001 waqf al-Nuqud.

[5] M. A. M. Hskafi, (d.1088 A. H.). Durr al-Mukhtar in Hashiyah Ibn Abidin. Vol. 4. Beirut: Dar al-Kutub al-Ilmiyah, 1992.

[6] J. E. Mandaville. Usurious piety: the cash waqf controversy in the Ottoman empire. International Journal of Middle East Studies. 1979, 10: $289-308$

[7] K. A. Ibn Humam, (d. 861 A. H.). Fath al-Qadir. Vol 6. Beirut: Dar al-Fikr, Nd.

[8] L. T. Peng. The Business of Banking in Malaysia. Selangor: Pelanduk Publications. 1998

[9] M. A. Dawwabah. Taswwur muqtarah littamwil bi al waqf. Awqaf. 2005, 9, 48-75.

[10] M. A. Ibn Abidin, (d. 1252 A. H.). Radd al-Muhtar Ala Durr al-Mukhtar. Vol. 4. Dar al-Kutub al-Ilmiyah, 1992.

[11] M. A. R. Tabtaba'i. Arkan al-waqf fi al-fiqh al-lslami, dirasatan fiqhiyyatan muqarinatan. Awqaf. 2003, 5, 91-134.

[12] M. I. I. Bukhari, (d. 256 A. H.). Sahih al-Bukhari. Vol. 3. Bierut: Dar Ibn Kathir. 1993.

[13] M. M. Arnawut. Dawr al Waqf fi Mujtama'at al Islamiyyah. Bierut: Dar Fikr al Ma'asirah. 2005

[14] M. S. Khatib, (d. 968 A. H.). Mughni al-Muhtaj. Vol 2. Beirut: Dar al Ma'rifah. 1997.

[15] M. T. Sabit, A. H. M. Iman, and I. Omar. An Ideal Mechanism for the Development of Waqf Properties. A fundamental research project report submitted to the Research Management Centre (RMC), Universiti Teknologi Malaysia, 2006 (unpublished).

[16] Maiman. Waqf al-nuqud wa al-awraq al-maliyyah. A'mal Muntada Qadaya al-Waqf al-Fiqhiyyah al-Thaniyyah, Tahddiyyat Asriyyah wa Ijtihadat Shar'yyah. Kuwait: IDB, Kuwait Awqaf Public Foundation, 2006.

[17] Malaysia. Banking and Financial Institutions Act. 1989.

[18] Malaysia. Companies Act. 1965.

[19] Malaysia. Islamic Banking Act. 1983

[20] S. A. A. B. Dirdir, (d. 1201 A.H.). Al Sharh al Kabir. Egypt: Ihya al Kutub al Arabiyah. N.d.

[21] S. A. Dunya. Al-waqf al-naqdi, madkhal li tafil dawr al-waqf fi hayatina al-muasirah. Awqaf. 2002, 3, 57-82.

[22] S. A. M. Sarakhsi, (d. 490 A. H.). Al Mabsut. Bierut: Dar al Ma'rifah. 1986.

[23] T. D. Ibn Taymiyah, (d.728 A. H.). Majma' al-Fatawa. vol 31. Npp: Majma Malik Fahd.1995.

[24] VakifBank, Annual Report 2009. Banking Smart, "http://www.vakifbank.com.tr/dokumanlar/finansal/Annual Report 2 009.pdf"; http://www.vakifbank.com.tr/dokumanlar/finansal/Annual_ Report 20 09.pdf accessed on 15/3/2011.

[25] W. Zuhaili. Al-Fiqh Ala Madhahib al-Arba'ah. 1997, 10: 761.

[26] Y. S. Nawawi (d. 676 A. H.). Al-Majmu ala al Muadhdhab. N.PP: al Maktabah al Muniriyyah. N.d.

[27] Z. Ibn Nujaim, (d. 970 A. H.). Bahr al-Ra'iq. Vol 5. Cairo: Dar al-Kitab al Islami. $\mathrm{Nd}$.

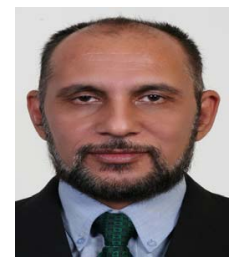

Mohammad Tahir Sabit Haji Mohammad. Skudai: Johor, Malaysia. Date of birth: 16/3/1961. Educational qualification: L.L.B. -1992; MCL-1993, studied at The Ahmad Ibrahim Kuliyyah of Laws, International Islamic University, Malaysia. PhD-Laws-2001. Now working as Associate Professor, Post Graduate Faculty member and Researcher at the Centre of Real Estate Studies, Faculty of Geoinformation and Real Estate, Universiti Teknologi Malaysia, Skudai, Johor, Malaysia. Dr. Mohammad Tahir Sabit has five PhDs and Published in the form of book, book-chapters, and13 research articles in journals and international conference proceedings. 